\title{
Tomato rugose mosaic virus in Tomato Crops in São Paulo State, Brazil
}

\author{
Addolorata Colariccio ${ }^{1}$, Jéssica C. Bergmann' ${ }^{\text {, Marcelo Eiras }}{ }^{1}$, Alexandre L.R. Chaves ${ }^{1}$, \\ César M. Chagas ${ }^{1} \&$ F. Murilo Zerbini ${ }^{2}$
}

${ }^{1}$ Laboratório de Fitovirologia e Fisiopatologia, Centro de Pesquisa e Desenvolvimento de Sanidade Vegetal, Instituto

Biológico, Av. Cons. Rodrigues Alves, 1252, CEP 04014-002, São Paulo, SP. E-mail: colariccio@biologico.sp.gov.br, ${ }^{2}$ Departamento de Fitopatologia/BIOAGRO, Universidade Federal de Viçosa, CEP 36571-000, Viçosa, MG.

(Accepted for publication 29/12/2006)

Author for correspondence: Addolorata Colariccio

\author{
RESUMO \\ Presença do Tomato rugose mosaic virus em cultivos de tomateiro no Estado de São Paulo, Brasil \\ Em levantamento realizado em cultivos de tomateiro no Estado de São Paulo, identificou-se o Tomato rugose \\ mosaic virus (ToRMV) associado a sintomas de redução de crescimento, mosaico e rugosidade foliar.
}

Geminiviruses were of limited economic importance to tomato crops until the introduction of Bemisia tabaci biotype B, when an increase in the incidence of begomovirus was reported (Ribeiro et al., Arch. Virol. 148:281. 2003). In recent years, the occurrence of geminivirus in tomato causing a severe outbreak has been observed in the Campinas region, SP. In preliminary surveys Tomato yellow vein streak virus (ToYVSV) turned out to be the most frequent begomovirus species, affecting about $70 \%$ of tomato crops. Occasionally, however, another possible begomovirus, inducing leaf crumple, has been noticed affecting tomato in that region (Colariccio et al., Summa Phytopathol. 27:105. 2001). The present work aimed to identify the virus associated with the leaf crumple symptom. Thus, leaf samples from affected 'Carmen' tomato plants from Mogi Guaçu, SP, showing growth reduction, green and yellow mosaic, besides leaf crumple and curling, were submitted to electron microscopy, mechanical, graft and Bemisia tabaci transmissions, as well as DNA extraction for PCR using universal primers (Rojas et al., Plant Dis. 77:340. 1993). Sequencing and phylogenetic analysis were performed to compare this virus with other geminivirus sequences deposited in the GenBank. Typical geminated particles were observed in negatively stained preparations from foliar veins. In situ observation revealed the presence of hexagonally-packed crystalline array or of loose aggregates in the nuclei of phloem-infected parenchyma cells, with partial alteration of nucleoli into a granular structure. These cytopathic effects corresponded to those described for begomoviruses. The virus was transmitted by $B$. tabaci and graft, but not mechanically, like Tomato rugose mosaic virus (ToRMV) from Minas Gerais State. A DNA-A fragment of about $1.2 \mathrm{kbp}$ was amplified, and the sequence showed $98 \%$ identity with ToRMV-[MG-Ub1] isolated in Minas Gerais, Brazil. They also shared the same cluster in the phylogenetic tree (Fig. 1). These results indicate that the begomovirus isolated in the present work is an isolate of ToRMV, named ToRMV-SP. In the twelve tomato-growing regions surveyed, ToRMV was found infecting tomatoes in only one. ToRMV was first described in
Minas Gerais (Fernandes et al. Fitopatol. Bras. 25: 440. 2000), and the complete sequencing of ToRMV-SP is required for further comparative studies.

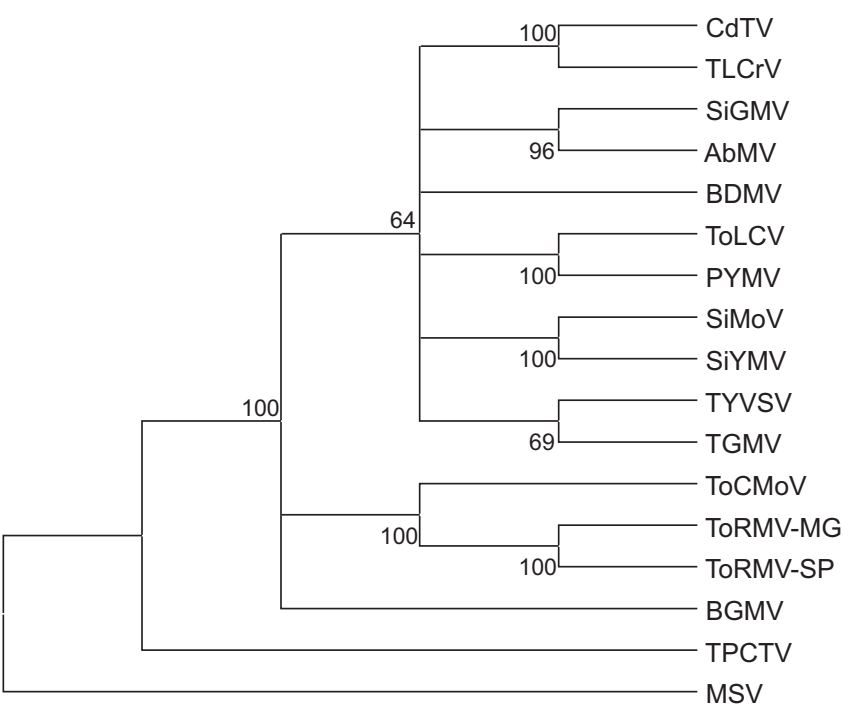

FIG. 1 - Phylogenetic tree based on the multiple alignment of geminivirus coat protein nucleotide sequences. The tree was generated with Mega 2.1, using the Neighbor Joining method. Bootstrap percentage values are shown at each branch. TPCTV - Tomato pseudo curly top virus, Topocuvirus (X84735) and MSV - Maize streak virus, Mastrevirus (K02026) were used as outgroups. CdTV - Chino del tomate virus (AF226665); TLCrV - Tomato leaf crumple virus (L34747); SiGMV - Sida golden mosaic virus (AF049336); AbMV - Abutilon mosaic virus (X15983); BDMV - Bean dwarf mosaic virus (M88179), ToLCV - Tomato leaf curl virus (Y15034); PYMV - Potato yellow mosaic virus (AF039031); SiMoV - Sida mottle virus (AY090555); SiYMV - Sida yellow mosaic virus (AY090558); TYVSV - Tomato yellow vein streak virus (U79998); TGMV - Tomato golden mosaic virus (NC_001507); ToCMoV - Tomato chlorotic mottle virus (AF490004); BGMV - Bean golden mosaic virus (M88686); ToRMVMG and ToRMV-SP - Tomato rugose mosaic virus from Minas Gerais (AF291705) and São Paulo, respectively. 